\title{
Impact of Local employee Guanxi on Job Satisfaction and TurnoverIntention: the Mediating Role of Job Security
}

\author{
Mohammed Abdulwahab Alwaheeb \\ Huazhong University of Science \& Technology, Wuhan, Pr China \\ Kingdom of Saudi Arabia \\ Liao Jianqiao \\ Huazhong University of Science \& Technology, Wuhan, Pr China
}

doi: 10.19044/esj.2016.v12n2p170 URL:http://dx.doi.org/10.19044/esj.2016.v12n2p170

\begin{abstract}
In the recent past, Saudi Arabia has experienced an influx of foreign workers. Most of the jobs that were traditionally occupied by the locals are now taken up by foreign workers. We explore the Guanxi and country policies that have dictated the job situation in this particular region. (Cooper, 2006) In this article we look into the both literature review and research methodologies used in the study. The exchange favors and the relationships created with business mindset are as well suggested.

Additionally this article elaborates on the research type of research used in establishing the predetermined objectives. Data sampling methods and their significance are considered. It gives a reflection on the real Guanxi policies on the job market currently (Eisenberger, 2001). The article investigates the policies implemented to curb conflict development between locals and foreigners. The implications of the Guanxi policies are implemented. Given that the locals are now skilled to occupy the jobs but are still missing the opportunities.
\end{abstract}

Keywords: Guanxi, job satisfaction, job security, turnover intention, organizational justice

\section{Introduction}

Guanxi and country policies to accept foreign workers to take up local job opportunities are two factors that are affective on the job situation in Saudi Arabia. Guanxi is a Chinese terminology with no basic word for word translation into English. As a result, many authors have identified it as an untranslatable word. Simply, it refers to the various relationships that individuals may engage in that will usually result in the exchange of favors. 
To put this terminology into a business mindset, it refers to the networks that one may create through social relations resulting in benefit for both parties that are involved. According to the Chinese society, this is a basic means of business operations and many of the entrepreneurs and tycoons may be seen engaging in the formation of such relationships. This has been a tradition that has been carried out in China and the communities involved for quite a long time and hence it is nearly impossible to break. However, in other parts of the world, it is identified as a time consuming prospect of carrying out the various business operations among various industries.

In the recent years, Saudi Arabia has been seen to provide numerous job opportunities in the private sector as well as the public sector. The public sector overtime has proved to offer better terms as to private sector (Feilzer, 2010) this has been the propelled by the introduction of local market policy that has accepted foreign workers to take up various roles in the local job opportunities. This policy is seen to have both negative and positive consequences. One positive impact of this policy could be the increase of professionals in the local market pool of potential employees. These professionals may influence the production of more jobs through innovation and entrepreneurship within the country. On the other hand, this policy may cause the deterioration of morale among the local employees (Azeem and Akhtar, 2014). Hereby, the market policy's openness to foreigners may cause local workers to feel that the various job posts that they hold could be potentially lost to the more qualified foreigners. These local employees may also seek to quit their jobs in the private sector and opt for jobs within the public sector.

\section{Theoreticalbackground \\ Guanxi}

The practice of guanxi in the employment and promotion procedures will cause the workers to question their positions in the firm (Niehoff \& Moorman, 1993). Guanxi is a type of relationship which is marked by the exchange of favors in personal relationships. According to So and Walker (2006) Guanxi is simplified by saying if Antony has delivered a certain support or assistance to Burke then, it is anticipated that Burke will recompense this to Antony later, even though not automatically under similar conditions. Alternatively, if Antony does not give any favors to Burke then, Burke will not do any favor for Antony either. So and Walker (2006) favors given by a person are important to a person in China even if the support or help was from a person who is not known. So, we come up with the following hypothesis:

H1: Guanxi will be positively related to Job Satisfaction

H2: Guanxi will be negatively related to Turnover Intentions. 
H3: Guanxi will be positively related to Job Security.

\section{Job security}

The open policy to foreigners in Saudi Arabia has made it one of the highly sort for job markets in the where foreigners are open to work in the country with minimal restrictions. As a result, the dynamism of hiring and job trends makes it uncertain for individuals to hold their jobs. There is a trend in the country where the private sector tends to hire more foreigners than natives escalating the uncertainty (Al-Waqfi \& Forstenlechner, 2010). The private sector is in the process of adopting a system that will absorb more locals into the Human Resources departments. Job security mainly focuses on retaining the job with current employer in the market (Liden R. C., 1980). Consequently the foreigners have a fear that other people will come and replace them from their positions or may have a hard time moving up the corporate ladder. Nonetheless, Guanxi affect dictates that those who perform better will be favored. A conclusion can be made that job security has a strong influence on job satisfaction as well turnover intentions for employees. Thus, we bring the following hypotheses:

H4a: Job Security will be positively related to Job Satisfaction

H4b: Job Security will be negatively related to Turnover Intention

H5a: Job Security mediates the relationship between Guanxi and Job Satisfaction

H5b: Job Security mediates the relationship between Guanxi and Turnover Intention

\section{Job satisfaction}

In the Saudi Arabian society, guanxi is defined by social interaction among other factors. There is a high tendency for employees to create a large circle of friends especially with people in the same industry and position. This circle of friends beyond the organization creates the opportunity to learn more about the industry's developments. In most cases, employees who interact in a Guanxi relationship tend to share sensitive information about the organizations in which they are employed. Consequently, the individual becomes more knowledgeable about the required conditions of work that the organization may not be implementing. Implicatively, the employees might raise issues in a bid to improve the situation but if the management is not willing to improve, then, the employees may get dissatisfied. More dissatisfaction with the current work environment or conditions is fueled by the fact that they may use their guanxi with other employees to seek employment elsewhere. Guanxi between supervisor- and employee plus employer-employee Guanxi affects the employee's satisfaction in equal measure to turnover intentions. 
A good relationship between the employer and the employees foster job satisfaction and promotes performance because the junior has opportunities that others do not have. The relationship foster's the employee way towards self-actualization, which leads to more satisfaction in the current position and organization to the level where Guanxi does not work in the employee's favor (Abosag \& Naudé, 2014). On the other hand, the opposite effect may occur if employees detect unfair treatment. Astoundingly, just as turnover intent, job satisfaction is impacted by other factors such as the culture of the organization (Scott et al., 2014). Conclusively, the effect of Guanxi on the turnover intention and job satisfaction is very similar. Conversely, the lack of good relationships between employees and the management leads to lower performance and job satisfaction having a negative impact on turnover intention.

\section{Turnover intention}

Individuals who create networks beyond their current organizations tend to be more affected by turnover intent since they constantly compare the conditions in the two organizations (the one he/she works in and the one his peers are positioned). The lack of better opportunities in other firms makes employees to stay in the current firm for long periods. Guanxi encompasses some values such as mutual benefits, doing and returning favors, and personal loyalty. Creating connections with others therefore, leads employees to exploit the new opportunities through the connection, which increases the turnover intention. Yet, the turnover intention that comes from Guanxi in such settings depends on more organization-specific factors.

The subordinate-supervisor Guanxi is not the best indicator of turnover intention in an organization. The subordinate-supervisor Guanxi explains the relationship that utilized interpersonal connection between those in higher positions and a junior employee (Scott et al., 2014). In Saudi Arabia, the interpersonal connections tend to be asymmetrical and only one partly benefits from Guanxi most of the time.

\section{Methodology}

\section{Participant and procedure}

Sampling started with the selection of target companies in the private sector from the list of companies provided by the Saudi Arabian Chamber of Commerce. The selection of companies with at least 100 employees provided assurance that the companies had multi-faceted organizational structures. It was also important to focus on the companies proving opportunities to both locals and expatriates with either having a percentage between 20 percent and 80 percent. The identified range was essential in acquiring knowledge about the role of organizational justice and hiring 
practices among other research variable such as employability. It was also crucial to consider the distribution of the firms in the Kingdom; selection based on the 10 regions provided a convenient platform to provide results indicative of the reality in Saudi Arabia. Finally, it was necessary to include firms operating in various industries ranging from construction, gas and oil, banking and insurance, higher education, media and advertising, healthcare, and travel. The researcher identified 35 companies from which a sample of 500 employees were to participate that suited the mentioned standards. Local workers, especially the highly educated ones study in Western universities, which make it easy for them to understand English better than Arab. It was prudent to consider the most suitable language for the participants without significant variation in the content of the questionnaires. Therefore, it was necessary to translate and harmonize the meanings of phrases and words in to the two principal languages, which required the contribution of three language experts with PhD degrees. It was only through the most qualified translators that it was possible to reduce the differences in the questionnaires. The distribution of the questionnaires adopted an electronic method as it is significantly convenient on time and resources. The researcher sent the questionnaire link to the heads of the 35 identified companies, who were responsible for distributing and collecting the answered questionnaires from employees within their organizations. Distribution and collection of the questionnaires took a period of 4 weeks as it was important that the participants had enough time to provide their responses. The researcher received 435 questionnaires, from which 20 of them were incomplete; the completed questionnaires (435-20) represented 83 percent of the sampled population, which is a significantly high response and completion rate. Sample of this study involved employees. The main factors were age, gender and education. All these factors may have negative or positive impacts on the behavior of the employees. Confidentiality was assured to the subjects to ensure genuine response. A total sample of 415 subjects was included in the analysis. These subjects were amongst the employees.

\section{Measuresment}

\section{Guanxi}

Guanxi refers to the action of utilizing social networks in the business and its various operations that originated from China (Elamin, 2011). Various authors ascertain that this system of operation originates from the Chinese community where it is widely practiced and is a major factor in ensuring positive relations between firms and its numerous stakeholders. The research by Hutchings and Weir (2006) connotes that numerous studies hitherto have been conducted in the Chinese market as opposed to the Arabic countries that is its main focus. As a result, it is necessary to point out the 
numerous practices of these people in their quest to form business networks in the various industries. The research introduces a new terminology, wasta, as an Arabic word that means nepotism or loosely related to "who you know” a phrase usually used in explaining the meaning of guanxi.

\section{Job security}

Another hypothesis created is that Guanxi of the locals positively influences their job security. In this case, the relationship between the supervisor and the employees is observed with the better relationship presenting higher levels of job security among workers and lower desire to change profession. The 8 item scale measure used in this the Leader-Member Exchange questionnaire that was developed by Liden and Graen (1980). A five point Likert scale will be used where 1 means "strongly disagree" and 5 for "strongly agree". For instance the LMX questionnaire will ask, "My supervisor would be inclined to help me solve problems in the task." Strongly agreeing with the statement will demonstrate positive job security as the employees do not fear making mistakes as they have assistance from the colleagues resulting in high job satisfaction and low levels of turnover intentions (Morrison, 2004). Alternatively, strong disagreement will demonstrate the contrary.

The relationships vary with intensity from those that absorb the basic terms of the employment contract and those that have a deeper value for reciprocation of influence, mutual trust, respect, and individual attachment. Higher levels of LMX have corresponding values of organizational commitment, job satisfaction, and job security but lower turnover intention (Liden, 1998). The current study adopted 8 items of the LMX model such as "My supervisor and I have a healthy relationship."

\section{Job satisfaction}

According to Bérubé et al. (2007), the Overall Job Satisfaction scale developed by Brayfeild and Rothe is one of the most comprehensive and popular global job satisfaction measures as it does not focus on the cognitive but rather affective evaluations. The principal advantage of using the global job satisfaction scale is that they are effective in the measurement of the overall job satisfaction of employees instead of focusing on particular jobs (Williams, \& Anderson, 1991). The development of a shorter 5-item scale helped reduce the redundancy of the longer 18-item scale; the scale uses a five-point Likert scale where $(1=$ strongly disagree to $5=$ strongly agree). The sampling includes: "At this very moment, I am enthusiastic about my work." 


\section{Turnover intention}

The prevalence of absenteeism among local employees in these private enterprises will demonstrate a high turnover intention. The use of the Kelloway, Gottlieb and Barham (1999) scale of 4 items will be utilized to measure the employee turnover intention of employees with the reference to as 5-point Likert scale. The scale presents the turnover intention as the outcome or end result of a process, although it does not identify the specific causes. Although the scale developed from the study of conflicts within the family structure, researchers such as Karavardar (2014) have applied it to measure employee turnover intention efficiently. A fall in business activities may be gradual but the effects can to effect after a sufficient period of time (Smith, 2008).

\section{Sampling procedures}

The main idea of this study is to determine correlations amongst employees, job security, job satisfaction and turnover intention. These four variables have unique characteristics which are analyzed independently. Sampling is the best method of obtaining data from large populations. Large population accountably poses constraints on researchers and occasionally a lot of resources may be spent (Cohen-Charash, 2001). Any task undertaken by any person or company strives to limit overall duration spent as well as the amount of inputs required. It may be time consuming to gather information from every element of a given population. Thus a small number the employees were taken and based on this assumption was made.

One of the assumptions was that the information expected from each element was genuine (Devrimci, 2013). Investigating the high turnover of saudi nationals versus non-nationals in private sector companies using selected antecedents and consequences of employee engagement. These samples are examples of external validity where generalizations to entire population are made from the overall data obtained by sampling (Bosma, 2010). Enhancing the probability that a particular study will contribute to the formulation of general laws in the real world can be done from specific research applying several samples.

\section{Analytical strategy Reliability and correlation analysis}

The data above proves to be reliable only if special variables are obtained. Means and standard deviations are already given in the tables above. The only remaining variable is correlation which is easily calculated from the means. The samples used were from the population under study. The population is the local people who are the employees. For clarity purposes, table for mean and standard deviation is given below. 
Table 1: Descriptive Statistics, Correlation Coefficients, and Cronbach’s Alpha

\begin{tabular}{|c|c|c|c|c|c|c|}
\hline & Mean & SD & GU & JOB & TI & JS \\
\hline GU & 2.82 & 1.03 & $(0.95)$ & & & \\
JOB & 3.31 & 0.72 & $0.60^{* *}$ & $(0.74)$ & & \\
TI & 3.10 & 1.42 & $-0.22^{* *}$ & $-0.21^{* *}$ & $(0.72)$ & \\
JS & 3.35 & 0.84 & $0.17^{* *}$ & $0.22^{* *}$ & 0.09 & $(0.94)$ \\
\hline
\end{tabular}

$\mathrm{N}=415,{ }^{*} \mathrm{p}<0.05 ;{ }^{* *} \mathrm{p}<0.01 ; * * * \mathrm{p}<0.001 ; \mathrm{GU}=$ Guanxi; JOB= Job Security; TI= Turnover Intention; JS= Job Satisfaction.

In this table, mean and standard deviation of each variable included in the model are presented along with Cronbach's Alpha in diagonal position for each variable ranging from minimum 0.72 for Turnover Intention to 0.95 for Guanxi. This shows appropriate and acceptable good level of internal reliability and consistency within the variables.

Guanxi was positively related to Job Security $(r=0.60, p<0.01)$, also positively related to Job Satisfaction $(r=0.17, p<0.01)$, but negatively related to Turnover Intention ( $r=-0.22, p<0.01)$. Similarly, Job Security was positively related to Job Satisfaction $(r=0.22, p<0.01)$, , and negatively related to Turnover Intention $(r=-0.21, p<0.01)$, These results showed as expected in theoretical conceptualization and as per developed hypothesis in this study.

\section{Confirmatory}

Table 1.1 presents the results of confirmatory factor analysis conducted through alternative models for all factors included in this study including Guanxi, Job Security, Job Satisfaction, and Turnover Intention. Four-factor model which is also the baseline model included all four variables in this research model. In four-factor model, the value of CFI is above the recommended level of 0.95 Root Mean Square Error of Approximation $($ RMSEA $)=0.06$, Comparative Fit Index $(\mathrm{CFI})=0.96$ were obtained under four-factor model.

In one-factor model all items were included in one latent variable as depicted by Goodness of Fit Index of 0.96 under four-factor model. Other variables are; $\mathrm{df}=317, \mathrm{GFI}=0.75$, $\mathrm{RMSEA}=0.17, \mathrm{CFI}=0.74$ and $\mathrm{NNFI}=$ 0.73. As compared with baseline model the two-factors and one-factor model did not achieved the recommended level of model fitness. Thus, only fourfactors model i.e. baseline model achieved the recommended model fitness. 
Table 2: Results of Confirmatory Factor Analyses

\begin{tabular}{|c|c|c|c|c|c|c|c|c|}
\hline Model & $\mathrm{x}^{2}$ & Df & GFI & RMSEA & CFI & NNFI & $\Delta \mathrm{x}^{2}$ & $\Delta \mathrm{df}$ \\
\hline $\begin{array}{c}\text { One-factor } \\
\text { model }\end{array}$ & $4279.49 * * *$ & 317 & .75 & .17 & .74 & .73 & $3375.21 * * *$ & 02 \\
\hline $\begin{array}{c}\text { Two-factor } \\
\text { model }\end{array}$ & $2154.62 * * *$ & 315 & .67 & .11 & .88 & .86 & $1250.34 * * *$ & 02 \\
\hline $\begin{array}{c}\text { Four-factor } \\
\text { model }\end{array}$ & $904.28 * * *$ & 313 & .88 & .06 & .96 & .95 & \multicolumn{2}{|c|}{ Baseline Model } \\
\hline
\end{tabular}

Note: $\quad n=415$; Four factors model refers to the proposed four factors in this study. In the two factors model job security, job satisfaction and turnover intention into one factor, and similarly, guanxi is used as one factor. In one factor model all items were included in one latent variable. GFI= Goodness of Fit Index; RMSEA= Root Mean Square Error of

Approximation; CFI= Comparative Fit Index; NNFI= Nonnormed Fit Index; *** $\mathrm{p}<.001$.

\section{Hypotheses testing}

To find out the main impact of Guanxi on job satisfaction and turnover intentions, hierarchical multiple regression analyses were carried out. The first regression analysis tests the effects of the independent variable i.e. Guanxi on dependent variables (job satisfaction, and turnover intention) and mediating variable (job security). H1, it was hypothesized that guanxi will be negatively related to turnover intentions. The results showed that guanxi is negatively related to turnover intentions $(\beta=-.23, p<0.001)$. So, hypothesis 1 was supported. H2, it was hypothesized that guanxi will be positively related to job satisfaction. The results showed that guanxi is positively related to job satisfaction $(\beta=.17, p<0.001)$. Thus, hypothesis 2 also supported. In hypothesis 3 , it was hypothesized that guanxi will be positively related to job security. The results of the study showed that guanxi is positively related to job security $(\beta=.60, p<0.001)$. Therefore, H3 was supported.

Table 3: Results of Multiple Regression Analysis on Turnover Intention and Job Satisfaction $\mathrm{n}=415,{ }^{*} \mathrm{p}<0.05 ; * * \mathrm{p}<0.01 ; * * * \mathrm{p}<0.001$

\begin{tabular}{|c|c|c|c|c|c|c|}
\hline \multirow{2}{*}{ Variable } & \multicolumn{2}{|c|}{ Turnover Intention } & \multicolumn{2}{c|}{ Job Satisfaction } & \multicolumn{2}{c|}{ Job Security } \\
\cline { 2 - 7 } & $\begin{array}{c}\text { Model } 1 \\
\beta\end{array}$ & $\begin{array}{c}\text { Model } 2 \\
\beta\end{array}$ & $\begin{array}{c}\text { Model } \\
1\end{array}$ & $\begin{array}{c}\text { Model } 2 \\
\beta\end{array}$ & $\begin{array}{c}\text { Model } \\
1 \\
\beta\end{array}$ & $\begin{array}{c}\text { Model 2 } \\
\beta\end{array}$ \\
\hline Gender & $.16^{* * *}$ & $.15^{* * *}$ & .01 & .02 & -.02 & -.01 \\
\hline Age & $-.11^{*}$ & $-.13^{*}$ & -.02 & -.01 & -.06 & -.02 \\
\hline Education & .03 & .03 & -.06 & -.06 & -.01 & -.02 \\
\hline $\begin{array}{c}\text { Nature of } \\
\text { Work }\end{array}$ & -.05 & -.06 & .03 & .04 & -.01 & -.00 \\
\hline $\begin{array}{c}\text { Work } \\
\text { Experience }\end{array}$ & .07 & .09 & -.03 & -.04 & .06 & .02 \\
\hline Guanxi & & $-.23^{* * *}$ & & $.17^{* * *}$ & & $.60^{* * *}$ \\
\hline $\mathrm{R}^{2}$ & .04 & .09 & .003 & .033 & .007 & .007 \\
\hline$\Delta \mathrm{R}^{2}$ & .04 & .05 & .003 & .030 & .364 & .357 \\
\hline$\Delta \mathrm{F}^{2}$ & $3.45^{* *}$ & $23.08^{* * *}$ & .283 & $12.626^{* * *}$ & .558 & $229.24^{* * *}$ \\
\hline
\end{tabular}


Table 4: Results of multiple regression analysis of Job Security on dependent Turnover Intention and Job Satisfaction

\begin{tabular}{|l|c|c|c|c|}
\hline \multirow{2}{*}{ Variable } & \multicolumn{2}{|c|}{ Turnover Intention } & \multicolumn{2}{c|}{ Job Satisfaction } \\
\cline { 2 - 5 } & $\begin{array}{c}\text { Model } 1 \\
\beta\end{array}$ & $\begin{array}{c}\text { Model } 2 \\
\beta\end{array}$ & $\begin{array}{c}\text { Model 1 } \\
\beta\end{array}$ & $\begin{array}{c}\text { Model 2 } \\
\beta\end{array}$ \\
\hline Gender & $.16^{* * *}$ & $.15^{* * *}$ & .01 & .02 \\
\hline Age & $-.11^{*}$ & $-.12^{*}$ & -.02 & -.01 \\
\hline Education & .03 & .03 & -.06 & -.06 \\
\hline Nature of Work & -.05 & -.05 & .03 & .04 \\
\hline Work Experience & .07 & .09 & -.03 & -.04 \\
\hline Job Security & & $-.21^{* * *}$ & & $.22^{* * *}$ \\
\hline $\mathrm{R}^{2}$ & .040 & .086 & .003 & .003 \\
\hline$\Delta \mathrm{R}^{2}$ & .040 & .046 & .053 & .050 \\
\hline$\Delta \mathrm{F}^{2}$ & $3.451^{* *}$ & $20.528^{* * *}$ & .283 & $21.516^{* * *}$ \\
\hline
\end{tabular}

$\mathrm{n}=415$, $^{*} \mathrm{p}<0.05 ;{ }^{* *} \mathrm{p}<0.01 ;{ }^{* * *} \mathrm{p}<0.001$;

Second set of regression analysis were carried out to investigate the impact of mediating variable (job security) on dependent variables (job satisfaction, and turnover intention). In hypothesis 4a, it was hypothesized that job security will be positively related to job satisfaction. The results showed that job security was positively related to job satisfaction $(\beta=.22$, $p<0.001$ ). So, hypothesis $4 \mathrm{a}$ was supported. In hypothesis $4 \mathrm{~b}$, it was hypothesized that job security will be negatively related to turnover intentions. The results of the study showed that job security was negatively related to turnover intention $(\beta=-.21, p<0.001)$. Therefore, hypothesis $4 \mathrm{~b}$ was also supported.

Table 5: Hierarchical Multiple Regression Analysis for Mediation Analysis

\begin{tabular}{|c|c|c|c|c|c|c|}
\hline \multirow{2}{*}{ Variable } & \multicolumn{3}{|c|}{ Turnover Intention } & \multicolumn{3}{c|}{ Job Satisfaction } \\
\cline { 2 - 7 } & $\begin{array}{c}\text { Model 1 } \\
\beta\end{array}$ & $\begin{array}{c}\text { Model } 2 \\
\beta\end{array}$ & $\begin{array}{c}\text { Model 3 } \\
\beta\end{array}$ & $\begin{array}{c}\text { Model 1 } \\
\beta\end{array}$ & $\begin{array}{c}\text { Model 2 } \\
\beta\end{array}$ & $\begin{array}{c}\text { Model 3 } \\
\beta\end{array}$ \\
\hline Gender & $.16^{* * *}$ & $.15^{* * *}$ & .15 & .01 & .02 & .02 \\
\hline Age & $-.11^{*}$ & $-.13^{*}$ & -.13 & -.02 & -.01 & -.01 \\
\hline Education & .03 & .03 & .03 & -.06 & -.06 & -.06 \\
\hline $\begin{array}{c}\text { Nature of } \\
\text { Work }\end{array}$ & -.05 & -.06 & -.06 & .03 & .04 & .04 \\
\hline $\begin{array}{c}\text { Work } \\
\text { Experience }\end{array}$ & .07 & .09 & .09 & -.03 & -.04 & -.04 \\
\hline Guanxi & & $-.23^{* * *}$ & $-.15^{* *}$ & & $.17^{* * *}$ & .06 \\
\hline Job Security & & & $-.12^{*}$ & & & $.19^{* *}$ \\
\hline$R^{2}$ & .040 & .092 & .101 & .003 & .033 & .056 \\
\hline$\Delta R^{2}$ & .040 & .051 & .010 & .003 & .030 & .022 \\
\hline$\Delta F^{2}$ & $3.451^{* *}$ & $23.080^{* * *}$ & $4.354^{*}$ & .283 & $12.626^{* * *}$ & $9.645^{* *}$ \\
\hline
\end{tabular}

$\mathrm{n}=415, * \mathrm{p}<0.05 ;{ }^{* *} \mathrm{p}<0.01 ;{ }^{* * *} \mathrm{p}<0.001 ;$ 
To test the mediation effect of job security further regression analysis were carried out. The results are shown in table 5 . It was hypothesized in hypothesis 5 a that job security will mediate the relationship between guanxi, and turnover intention. The results showed that job security negatively mediated the relationship between guanxi and turnover intention $(\beta=-.12$, $p<0.05$ ). In hypothesis $5 \mathrm{~b}$, it was hypothesized that job security will mediate the relationship between guanxi and job satisfaction. The results of the study showed that job security positively mediated the relationship between guanxi and job satisfaction $(\beta=.19, p<0.01)$. This model accounted for 5.6 percent of the variance $\left(R^{2}=.056\right)$. Thus, hypothesis 5 a and $5 \mathrm{~b}$ were also supported.

\section{Discussion}

Our reasoning was also confirmed for both guanxi positively related to job satisfaction and guanxi negatively related to turnover intentions. The results also showed that job security mediates the relationship between guanxi and both dependent variables in this study i.e. job satisfaction and Turnover Intention. The study showed that job security mediates the relationship between Guanxi and Turnover Intention. Also Guanxi is positively related to job satisfaction. These are a few statements that can be defined from this documented study. The study presented the conceptualization based on literature review and further empirical assessment that Guanxi has a stronger influence on employees feeling of job security when it is higher and in return it increases the impact on increased job satisfaction of employees having stronger and healthy employment relations within organization. Similarly, study also found that having stronger relationship based on Guanxi construct reduces the turnover intentions of employees and makes them more satisfied in return.

\section{Implications and conclusion}

First, the relationships amongst job security, job satisfaction and turnover intention concurs with the research of Restubog (2008). Although their studies base on different topics, conclusions are similar. These similarities make it necessary to apply the theory in my conclusion. The second idea being discussed is the positivity between job satisfaction and Guanxi. In most cases employees engage in their daily activities with different notions. Most of them aim at securing salaries and other benefits but other look into satisfying their employers. The two categories are much alienated from each other. In the long term, those who satisfy employers end up benefiting from salary increase and maybe promotions. Although this is not always the case, the applications have been proved liable. If a business or a company grows, employees are advantaged. Most employees fail to put job satisfaction in mind and this is why they are positively related. 
The findings of the study can be used by managers to improve the employment relations. Organizations should always strive at encouraging employees to work diligently. According to a study (Morrison \& Robinson, 1997), employees should be provided with adequate explanation on various contracts. Also sufficient training is necessary to curb noncompliance amongst the employees. Better management is evident if both the management and the employees are satisfied with each other (Mellahi, 2001). If obligations of each partner are fulfilled, there will be minimal interparty misunderstandings. Employees' welfare must be observed for them to feel safe.

\section{Limitations and directions of the future research}

This research encountered several challenges and limitations. The first one was the average mean values and standard deviations. Literally these values may vary from the accepted data but they have implications on the overall conclusions. Acknowledgement should be given to the relationships among the affected variables (Ling Yu So, 2006). Especially those that show positive outcomes should have more considerations. In such scenarios, proper decisions are vital in management (Dwivedi, 1998). Future research may incorporate engagement, and involvement factors as a mediator to further see the commitment based on stronger Guanxi influence.

\section{References:}

Abosag, I., \&Naudé, P. (2014). Development of special forms of B2B relationships: Examining the role of interpersonal liking in developing Guanxi and Et-Moone relationships. Industrial Marketing Management, 43(6), 887-896. http://dx.doi.org/10.1016/j.indmarman.2014.05.003

Al-Waqfi, M., \& Forstenlechner, I. (2010).Stereotyping of citizens in an expatriate-dominated labour market. Employee Relations, 32(4), 364-381. http://dx.doi.org/10.1108/01425451011051596

Azeem, S. M. and Akhtar, N. (2014) Job Satisfaction and Organizational Commitment Among Public Sector Employees in Saudi Arabia. International Journal of Business and Social Science, Vol. 5 (7): 127-133.

Bérubé, N., Donia, M., Gagné, M., Houlfort, N., \&Koestner, R. (2007).Validation of the satisfaction with work scale.In ASAC, 28, (5).

Bosma, N. S. (2010). Global Entrepreneurship Monitor 2009 Executive Report. dspace.library.

Cohen-Charash, Y. \&. (2001). "The role of justice in organizations: ameta analysis”, Organizational Behavior and Human Decision Processes, . 86(2), 278-321.

Cooper, D. R. (2006). Business Research Method, 9th Edition. Boston:: McGraw-Hill Irwin. 
Devrimci, A. B. (2013). A Qualitative Study on the Antecedents of Turnover Intentions in A Turkish Company. The Journal of American Business Review, , 1(2), 158-164.

Dwivedi, S. (1998). Turnover Intentions: Scale Construction \& Validation . Journal of Industrial Relations, Vol. 50, No. 3.

Eisenberger, R. A. (2001). Reciprocation of perceived organizational support. Journal Of Applied Psychology, , 86(1), 42-51.

Elamin, A. M. (2011). Does organizational justice influence job satisfaction and self-perceived performance in Saudi Arabia work environment. International Management Review, pp. , 7 (1), 38-49.

Feilzer, M. Y. (2010). Doing Mixed Methods Research Pragmatically: Implications for the Rediscovery of Pragmatism as a Research Paradigm. . Journal of Mixed Methods Research, 4(1), 6-16.

Hutchings, K. and Weir, D. (2006) "Understanding Networking in China and the Arab World: Lessons for International Managers”, Journal of European Industrial Training, Vol. 30 (40): 272-290.

Karavardar, G. (2014). Organizational Career Growth and Turnover Intention: An Application in Audit Firms in Turkey. IBR, 7(9).http://dx.doi.org/10.5539/ibr.v7n9p67

Kelloway, E.K., Gottlieb, B.H., \&Barham, L. (1999). The source, nature, and direction of work and family conflict: A longitudinal investigation. Journal of Occupational Health Psychology, 4,337-346.

Liden, R. (1998). Multidimensionality of leader-member exchange: An empirical assessment through scale development. Journal Of Management , 24(1), 43-72.

Liden, R. C., \&Graen, G. (1980).Generalizability of the vertical dyad linkage model of leadership.Academy of Management Journal, 23, 451-465.

ling yu so, a. w. (2006). Explaining gaunxi. new york: routledge.

Mellahi, K. \&. (2001). management in Saudi Arabia. Human resource management in developing countries,, 5, 135.

Morrison, E. W., \& Robinson, S. L. (1997). When employees feel betrayed: A model of how psychological contract violation develops. Academy of management Review, 22(1), 226-256.

Morrison, R. (2004). Informal Relationships in the Workplace: Associations with Job Satisfaction, Organizational Commitment and Turnover Intentions. New Zealand Journal of Psychology, 33: 114-128.

Niehoff, B. P. \& Moorman, R. H. (1993) “Justice as a Mediator of the Relationship between Methods of Monitoring and Organizational Citizenship Behavior”, Academy of Management Journal, Vol. 36, No. 5: 527-556.

Restubog, S. L. D., Hornsey, M. J., Bordia, P., \& Esposo, S. R. (2008). Effects of psychological contract breach on organizational citizenship 
behavior: Insights from the group value model. Journal of Management Studies, 45(8), 1377-1400

Scott, J., Harrison, R., Hussain, J., \& Millman, C. (2014). The role of Guanxi networks in the performance of women-led firms in China. IntJrnlOf Gen And Ent, 6(1), 68-82. http://dx.doi.org/10.1108/ijge-03-2013-0014 Smith, J. (. (2008). Qualitative psychology: A practical guide to research methods,. Los, Angeles : CA: SAGE Publications.

So, Y. L., \& Walker, A. (2006). Explaining Guanxi: the Chinese business network. London: Routledge.

Williams, L. \& Anderson, S. (1991). Job satisfaction and organizational commitment as predictors of organizational citizenship and in-role behaviors.Journal of Management, 17 (3), 601-617. 